\title{
The Association of Serum Osteopontin Levels with Insulin Resistance in Obese, Dyslipidemic Children
}

\author{
Sahin Hamilcıkan, ${ }^{1}$ Meltem Erol, ${ }^{1}$ Ozlem Bostan Gayret, ${ }^{1}$ Ovgu Buke, ${ }^{1}$ and Emrah Can ${ }^{1, *}$ \\ ${ }^{1}$ Department of Pediatrics, Bagcilar Training and Research Hospital, Istanbul, Turkey \\ "Corresponding author: Dr. Emrah Can, Associate Professor, Department of Pediatrics, Bagcilar Training and Research Hospital, Istanbul, Turkey. Tel: +90-5325123606, E-mail: \\ canemrahcan@yahoo.com
}

Received 2016 June 09; Revised 2016 November 30; Accepted 2016 December 20.

\begin{abstract}
Objectives: To assess serum osteopontin (OPN) concentrations and to evaluate the correlation between OPN levels and insulin resistance (IR) in obese dyslipidemic children.

Methods: The study featured 107 obese children with ages ranging between 3 - 17 years. Anthropometrical measurements and biochemical analyses were performed and serum OPN samples were obtained. IR was defined using the homeostasis model assessmentinsulin resistance (HOMA-IR) protocol.

Results: Of the 107 obese children that were recruited for the study, 63 were girls (58.9\%) and 44 were boys (58.9\%), with a mean age of $11.18 \pm 3.41$ years. Of them, $21(19.6 \%)$ were diagnosed with dyslipidemia. No significant differences in age and gender were identified between the dyslipidemic and non-dyslipidemic groups. The mean body mass index (BMI), fasting blood glucose, insulin, and alanine transaminase levels were similar in both groups $(\mathrm{P}=0.74)$. The average total cholesterol $(\mathrm{TC})$, low-density lipoprotein cholesterol (LDL), and triglyceride(TG) levels were higher, while the high-density lipoprotein (HDL) and cholesterol levels were lower in the dyslipidemic group. Amongst the children with dyslipidemia, 28 (84.84\%) had IR. The mean OPN levels in the dyslipidemic group were not found to be higher than the non-dyslipidemic group ( $46.94 \pm 25.64 \mathrm{vs} 48.92 \pm 24.45 ; \mathrm{P}=0.70$ ). Multivariate regression analysis confirmed that increased HOMA-IR levels $(\mathrm{P}=0.01)$ are an important risk factor for dyslipidemia.

Conclusions: While serum OPN levels were found to be related to IR in obese children, OPN levels were not associated with dyslipidemia.
\end{abstract}

Keywords: Osteopontin, Obesity, Dyslipidemia, Insulin Resistance

\section{Introduction}

Obesity-related insulin resistance (IR) has become a major childhood health problem. In previous studies, the numbers of activated monocytes and macrophages have been reported to be elevated in obese patients. The correlation of body mass index (BMI) and the number of macrophages suggests that the fat tissue may be one of the main sources of blood monocytes (1). Activated monocytes invade the fat tissue and promote chronic inflammation by releasing cytokines, which may be linked to the mechanisms of obesity-induced hormone resistance $(2,3)$. Osteopontin (OPN) is a multifunctional pro-inflammatory cytokine involved in tissue transforming and also plays a role in the pathogenesis of atherosclerosis and diabetes. Many studies have described OPN as an essential regulator of fat inflammation and IR. OPN expression has been found to be strongly upregulated by 40 and 80 folds in fat tissue from diet-induced and genetically obese mice, respectively, and the analysis of fat cellular fractions has shown that most of the OPN supply in both humans and murinae with genetic and diet-induced obesity are adipose tissue macrophages
(ATM) (4-6). OPN macromolecule expression may be iatrogenic from the spread of growth factors and cytokines, although the mechanisms of the upregulation remain not fully understood (7). In addition, OPN deficiency has improved glucose tolerance and reduced IR in mice, independent of body composition or energy expenditure (5). Insulin hormone resistance also plays a serious role in obesity. As the population gets heavier at younger ages, the age of onset of type 2 diabetes mellitus also decreases (8).

\section{Objectives}

In this study, we compared IR and serum OPN levels of obese dyslipidemic children to obese non-dyslipidemic children and expected higher levels of correlation of OPN and IR in the dyslipidemic group.

\section{Methods}

\subsection{Study Design}

A cross-sectional clinical trial was conducted in the outpatient clinic. Data related to age, anthropometric mea- 
surements, BMI, lipid profile, IR, liver function tests, and correlations between these parameters were assessed. Detailed physical examination and specified laboratory evaluations were performed for each patient. Standing height was measured to the nearest $0.1 \mathrm{~cm}$ with a Harpenden fixed stadiometer. Body weight $(\mathrm{kg})$ was measured with a SECA balance scale to the nearest $0.1 \mathrm{~kg}$, with each subject dressed similarly in lightweight clothing. The BMI was calculated by dividing the body weight (in kilograms) by the height (in meters) squared $\left(\mathrm{kg} / \mathrm{m}^{2}\right)$. A WHO chart was used for the BMI classification. Obesity was defined as BMI $>$ the 97th percentile, which is the definition of the international obesity task force $(9,10)$. Children diagnosed with specific obesity-associated syndromes and with endocrine disorders were excluded from the study. No history or evidence of current systemic disease was present. None of the participants used any medication. Blood analyses were performed after fasting. The study was affirmed by the local ethical committee and written consent was obtained from the parents of the participants of both groups.

\subsection{Sample Size Calculation}

Previous studies have reported high serum OPN concentrations in diet-induced and genetically obese children (11). Based on previous findings, we assumed that the sample size of this study would allow us to detect differences in OPN levels between the two groups $(\alpha=0.05$, power $=$ $80 \%$ ). The $\alpha$ level was set at 0.05 , based on a two-sided, twosample t-test.

\subsection{Laboratory Tests and Methods}

Cholesterol, high-density lipoprotein (HDL), lowdensity lipoprotein (LDL), and triglyceride (TG) levels were measured using the homogenous colorimetric enzyme technique (Roche, Modular-P 800). Glucose was evaluated by the glucose oxidase technique (Siemens ADVIA 1800) and insulin levels were analyzed with a direct chemiluminescence technique (Siemens ADVIA Centaur, USA). Serum OPN was measured by the ELISA (enzyme-linked immunosorbent assay) method using an ELX-800 system (RayBiotech, Norcross, GA, USA) and the urinary OPN was measured using enzyme-linked immunosorbent assay by Assay Designs (Ann Arbor, Michigan, USA). Serum total cholesterol (TC) levels over $200 \mathrm{mg} / \mathrm{dL}$, TG levels over $150 \mathrm{mg} / \mathrm{dL}$, LDL-C levels over $130 \mathrm{mg} / \mathrm{dL}$, or HDL-C levels under $40 \mathrm{mg} / \mathrm{dL}$ were accepted as dyslipidemia (12). IR was ascertained from the fasting plasma measurements using HOMA-IR index (insulin $(\mathrm{mU} / \mathrm{L}) \times$ glucose $(\mathrm{mmol} / \mathrm{L}) / 22.5)$ (6) and defined as a HOMA-IR index greater than 2.5 (9).

\subsection{Statistical Analysis}

The statistical analysis was performed using NCSS (Number Cruncher Statistical System) 2007. A t-test was used to calculate the differences between the groups. Associations were evaluated using logistic regression analysis. Categorical data were compared using the Chi-square test; $\mathrm{P}<0.05$ was accepted significant.

\section{Results}

This study featured 107 children (mean age $11.18 \pm 3.41$ years), 63 (58.9\%) who were girls and 44 (41.1\%) boys. Of these, 21(19.6\%) were diagnosed with dyslipidemia. No significant differences in age and gender were identified between the dyslipidemic and non-dyslipidemic groups. Detailed characteristics of the selected children are shown in Table 1.

Table 1. Descriptive and General Characteristics for the Groups ${ }^{\mathrm{a}}$

\begin{tabular}{|lccc}
\hline & $\begin{array}{c}\text { Dyslipidemic } \\
\text { Group(n: 21) }\end{array}$ & $\begin{array}{c}\text { Non- } \\
\text { Dyslipidemic } \\
\text { Group (n: 86 })\end{array}$ & P Value \\
\hline Age, & $10.96 \pm 3.68$ & $11.23 \pm 3.36$ & 0.744 \\
\hline Weight, kg & $67.48 \pm 27.28$ & $66.68 \pm 24.42$ & 0.896 \\
\hline Height, m & $1.46 \pm 0.21$ & $1.48 \pm 0.17$ & 0.755 \\
\hline BMI & $29.59 \pm 5.81$ & $29.19 \pm 4.94$ & 0.749 \\
\hline AC & $93.61 \pm 16.42$ & $92.13 \pm 12.78$ & 0.655 \\
\hline SBP, mmHg & $126.42 \pm 19.05$ & $120.57 \pm 12.69$ & 0.093 \\
\hline DBP, mmHg & $67.57 \pm 10.92$ & $67.44 \pm 8.17$ & 0.954 \\
\hline $\begin{array}{l}\text { Triglycerides, } \\
\text { mg/dL }\end{array}$ & $175.15 \pm 63.47$ & $97.16 \pm 34.39$ & 0.000 \\
\hline Glucose, mg/dL & $92.56 \pm 8.47$ & $89.85 \pm 8.46$ & 0.192 \\
\hline Insulin, mU/L & $28.52 \pm 19.31$ & $20.16 \pm 15.61$ & 0.039 \\
\hline HOMA-IR & $6.75 \pm 5.15$ & $4.49 \pm 3.83$ & 0.026 \\
\hline ALT, U/L & $34.10 \pm 23.45$ & $23.81 \pm 10.88$ & 0.004 \\
\hline AST, U/L & $25.72 \pm 9.77$ & $23.13 \pm 6.69$ & 0.153 \\
\hline $\begin{array}{l}\text { Serum } \\
\text { Osteopontin }\end{array}$ & $46.71 \pm 21.93$ & $48.71 \pm 25.46$ & 0.742 \\
\hline $\begin{array}{l}\text { Urine } \\
\text { Osteopontin }\end{array}$ & $237.17 \pm 140.75$ & $201.93 \pm 126.56$ & 0.720 \\
\hline IDL, mg/dL & $105.59 \pm 34.72$ & $90.45 \pm 23.00$ & 0.017 \\
\hline Aholesterol, & & $159.19 \pm 23.04$ & 0.000 \\
\hline
\end{tabular}

Abbreviations: AC, abdominal circumference, DBP, diastolic blood pressure; SBP, systolic blood pressure.

${ }^{\mathrm{a}}$ Values are expressed as mean $\pm \mathrm{SD}$.

The mean weight, height, abdominal circumference, mean systolic-diastolic blood pressure, and BMI were not 
found to differ between the groups. The mean TC was 181.05 \pm 28.64 vs. $159.19 \pm 23.04(\mathrm{P}=0.001)$ and LDL cholesterol was $105.59 \pm 34.72$ vs. $90.45 \pm 23.0(\mathrm{P}=0.017)$. TG levels (175.15 \pm 63.47 vs. $97.16 \pm 34.39 ; \mathrm{P}=0.001)$ were found to be significantly higher, while HDL-C levels (45.95 $\pm 15.04 \mathrm{vs.}$ $53.63 \pm 16.07 ; \mathrm{P}=0.05)$ were detected as significantly lower in the dyslipidemic group.

While the average fasting blood glucose was similar (92.56 \pm 8.47 vs. $89.85 \pm 8.46 ; \mathrm{P}=0.19$ ), insulin levels were found to be higher in the dyslipidemic group (dyslipidemic $28.52 \pm 19.31$ vs. non-dyslipidemic $20.16 \pm 15.61 ; \mathrm{P}=$ $0.03)$. Among the patients with dyslipidemia, the IR ratio was 18 (85.7\%).

The mean serum and urinary OPN levels were not significantly higher in dyslipidemic obese children (mean serum: $46.71 \pm 21.93$ vs. $48.71 \pm 25.46$; $\mathrm{P}=0.74$; urinary OPN: $237.17 \pm 140.75$ vs. $201.93 \pm 126.56$; $\mathrm{P}=0.30$ ) (Figure 1). Liver function tests were evaluated for both groups and mean ALT levels ( $34.10 \pm 23.45$ vs. $23.81 \pm 10.8 ; \mathrm{P}=0.04$ ) were found to be higher in children with dyslipidemia.

In the study group, regression analysis confirmed that an increase in OPN levels is an important risk factor in IR(P $<0.001$ ); there was no association between OPN levels and dyslipidemia in obese children (Table 2).

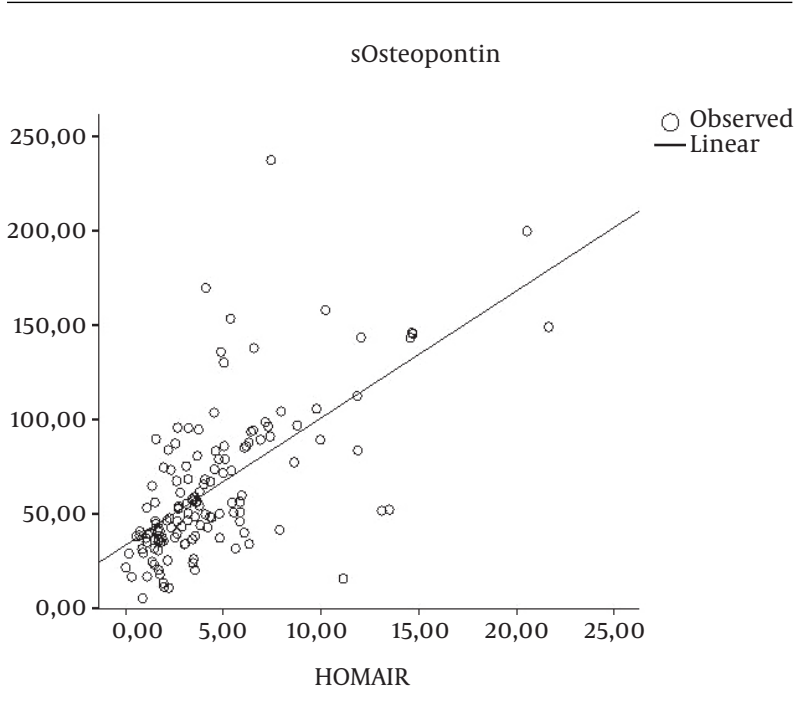

Figure 1. Regression Graphics for HOMAR-IR and Osteopontin

\section{Discussion}

Obesity has become one of the foremost public health issues globally (13-15). The prevalence of the co-morbidities related to obesity has also increased with the increasing obesity prevalence (16); therefore, health-care suppliers should identify overweight and obese children for proper and early treatment. Co-morbidities, such as type 2 diabetes mellitus and steatohepatitis, previously considered as "adult diseases," are now frequently seen in obese children. Obesity during adolescence, independent of obesity in adulthood, increases the risk of disease and premature death during adulthood (17-20). "Metabolic syndrome" is a term used to describe the clustering of metabolic risk factors for type 2 diabetes and atherosclerotic cardiovascular disease in adults: abdominal obesity, hyperglycemia, dyslipidemia, and hypertension. Several studies have estimated that approximately $10 \%$ of US adolescents have metabolic syndrome, as defined by modifications of adult criteria (21-23). Dyslipidemia occurs amongst overweight and obese children and adolescents, particularly those with a central fat distribution and increased adiposity (as measured by triceps skin-fold thickness $\geq 8$ th percentile). The typical pattern features raised concentrations of blood serum, LDL cholesterol, and TG and also reduced concentration of HDL cholesterol $(24,25)$.

The risk of these abnormalities increases with the severity of obesity (26). In our study, the mean age for obesity was found to be 11.18 years and the dyslipidemia ratio was $19.6 \%$ in these children. The mean cholesterol, LDL-C, and TG levels were higher, while the HDL-C level was lower in the dyslipidemic group.

In a study involving more than 6,000 sixth grade students (average age 11.8 years), nearly $20 \%$ were overweight and 30\% were obese. Impaired fasting glucose (FPG $\geq 100$ $\mathrm{mg} / \mathrm{dL}$ ) was present in $15.5 \%$ of overweight children, $20.2 \%$ of obese children, and $22.5 \%$ of severely obese children (27, 28).

The present study did not detect any difference in mean fasting blood glucose levels between the two groups, however, insulin levels were higher in the dyslipidemic group. High IR detected in the dyslipidemic group was not found to be significant.

OPN has been established as a major component in the development of adipose tissue inflammation and IR, and some human studies have focused on its role in patients with obesity. OPN expression in adipose tissue, as well as in circulating OPN levels, was substantially elevated in obese patients compared with lean subjects and was further increased in obese diabetic or insulin-resistant patients (29, 30). However, in our study, serum OPN levels were not found to be higher in the dyslipidemic group.

OPN is a secretory protein that also plays a significant role in urinary stone formation. In our study, no significant difference was detected in urinary OPN levels in dyslipidemic children.

Obesity is associated with a clinical spectrum of liver abnormalities collectively known as nonalcoholic fatty 
Table 2. Linear Regression Analysis Results for Osteopontin

\begin{tabular}{|c|c|c|c|c|c|c|}
\hline \multirow[t]{2}{*}{ Model } & & \multicolumn{2}{|c|}{ Unstandardized Coefficients } & \multirow{2}{*}{$\begin{array}{c}\text { Standardized Coefficients } \\
\text { Beta }\end{array}$} & \multirow{2}{*}{$\mathbf{t}$} & \multirow{2}{*}{$\begin{array}{l}\text { P Value } \\
\text { Std Error }\end{array}$} \\
\hline & & B & Std Error & & & \\
\hline \multirow{4}{*}{1} & (Constant) & -2.473 & 2.562 & & -0.965 & 0.337 \\
\hline & BMI & 0.228 & 0.079 & 0.277 & 2.875 & 0.005 \\
\hline & sOsteopontin & 0.009 & 0.016 & 0.054 & 0.570 & 0.570 \\
\hline & uOsteopontin & 0.001 & 0.003 & 0.042 & 0.443 & 0.659 \\
\hline
\end{tabular}

liver disease (NAFLD), the foremost reason for liver disease in childhood $(31,32)$. There are vital clinical associations between NAFLD and parts of the metabolic syndrome, as well as IR, dyslipidemia, and high blood pressure, regardless of the degree of obesity (33). We also found lower mean ALT levels ( $34.10 \pm 23.45$ vs. $23.81 \pm 10.8 ; \mathrm{P}=0.04)$ in nondyslipidemic children. With the increased prevalence of childhood obesity, NAFLD is increasingly seen in children (34). Previous studies have reported that the incidence of hepatosteatosis in obese children was 12 to $72.9 \%$ (27-29). Hepatosteatosis was detected by abdominal ultrasonography in $61.7 \%$ of obese children involved in our study.

In conclusion, while our findings confirmed the correlation with serum osteopontin levels and insulin resistance, increased osteopontin was not found related to dyslipidemia.

\section{References}

1. Kahles F, Findeisen HM, Bruemmer D. Osteopontin: A novel regulator at the cross roads of inflammation, obesity and diabetes. $\mathrm{Mol}$ Metab. 2014;3(4):384-93. doi:10.1016/j.molmet.2014.03.004. [PubMed: 24944898].

2. Weisberg SP, McCann D, Desai M, Rosenbaum M, Leibel RL, Ferrante AW Jr. Obesity is associated with macrophage accumulation in adipose tissue. J Clin Invest. 2003;112(12):1796-808. doi: 10.1172/JCI19246. [PubMed: 14679176].

3. Curat CA, Miranville A, Sengenes C, Diehl M, Tonus C, Busse R, et al. From blood monocytes to adipose tissue-resident macrophages: induction of diapedesis by human mature adipocytes. Diabetes. 2004;53(5):1285-92. [PubMed: 15111498].

4. Kiefer FW, Zeyda M, Todoric J, Huber J, Geyeregger R, Weichhart T, et al. Osteopontin expression in human and murine obesity: extensive local up-regulation in adipose tissue but minimal systemic alterations. Endocrinology. 2008;149(3):1350-7. doi:10.1210/en.2007-1312. [PubMed: 18048491].

5. Nomiyama T, Perez-Tilve D, Ogawa D, Gizard F, Zhao Y, Heywood EB, et al. Osteopontin mediates obesity-induced adipose tissue macrophage infiltration and insulin resistance in mice. J Clin Invest. 2007;117(10):2877-88. doi: 10.1172/JCI31986. [PubMed: 17823662].

6. Kiefer FW, Zeyda M, Gollinger K, Pfau B, Neuhofer A, Weichhart T, et al. Neutralization of osteopontin inhibits obesity-induced inflammation and insulin resistance. Diabetes. 2010;59(4):935-46. doi: 10.2337/db09-0404. [PubMed: 20107108].

7. Denhardt DT, Mistretta D, Chambers AF, Krishna S, Porter JF, Raghuram S, et al. Transcriptional regulation of osteopontin and the metastatic phenotype: evidence for a Ras-activated enhancer in the human OPN promoter. Clin Exp Metastasis. 2003;20(1):77-84. [PubMed: 12650610].

8. Sainger R, Grau JB, Poggio P, Branchetti E, Bavaria JE, Gorman $\mathrm{JH} 3 \mathrm{rd}$, et al. Dephosphorylation of circulating human osteopontin correlates with severe valvular calcification in patients with calcific aortic valve disease. Biomarkers. 2012;17(2):111-8. doi 10.3109/1354750X.2011.642407. [PubMed: 22191734].

9. Reinehr T, de Sousa G, Toschke AM, Andler W. Comparison of metabolic syndrome prevalence using eight different definitions: a critical approach. Arch Dis Child. 2007;92(12):1067-72. doi: 10.1136/adc.2006.104588. [PubMed:17301109].

10. Braga-Tavares H, Fonseca $\mathrm{H}$. Prevalence of metabolic syndrome in a Portuguese obese adolescent population according to three different definitions. Eur J Pediatr. 2010;169(8):935-40. doi: 10.1007/s00431-0101143-5. [PubMed: 20177702].

11. Lezhenko G, Gladun E. [The role of osteopontin and adiponectin in the development of insulin resistance and hypertension in obesed adolescents]. Georgian Med News. 2013(214):43-8. [PubMed: 23388534].

12. Daniels SR, Greer FR, Committee on N. Lipid screening and cardiovascular health in childhood. Pediatrics. 2008;122(1):198-208. doi: 10.1542/peds.2008-1349. [PubMed:18596007].

13. Valerio G, Licenziati MR, Iannuzzi A, Franzese A, Siani P, Riccardi G, et al. Insulin resistance and impaired glucose tolerance in obese children and adolescents from Southern Italy. Nutr Metab Cardiovasc Dis. 2006;16(4):279-84. doi: 10.1016/j.numecd.2005.12.007. [PubMed: 16679220].

14. Strauss RS, Pollack HA. Epidemic increase in childhood overweight, 1986-1998. JAMA. 2001;286(22):2845-8. [PubMed: 11735760].

15. Dietz WH, Robinson TN. Clinical practice. Overweight children and adolescents. N Engl J Med. 2005;352(20):2100-9. doi: 10.1056/NEJMcp043052. [PubMed: 15901863].

16. van Dam RM, Willett WC, Manson JE, Hu FB. The relationship between overweight in adolescence and premature death in women. Ann Intern Med. 2006;145(2):91-7. [PubMed: 16847291].

17. Must A, Jacques PF, Dallal GE, Bajema CJ, Dietz WH. Long-term morbidity and mortality of overweight adolescents. A follow-up of the Harvard Growth Study of 1922 to 1935. N Engl J Med. 1992;327(19):1350-5 doi: 10.1056/NEJM199211053271904. [PubMed: 1406836].

18. Must A, Phillips SM, Naumova EN. Occurrence and timing of childhood overweight and mortality: findings from the Third Harvard Growth Study. J Pediatr. 2012;160(5):743-50. doi: 10.1016/j.jpeds.2011.10.037. [PubMed: 22183448].

19. Bjorge T, Engeland A, Tverdal A, Smith GD. Body mass index in adolescence in relation to cause-specific mortality: a follow-up of 230,000 Norwegian adolescents. Am J Epidemiol. 2008;168(1):30-7. doi:10.1093/aje/kwn096. [PubMed:18477652].

20. Inge TH, King WC, Jenkins TM, Courcoulas AP, Mitsnefes M, Flum DR, et al. The effect of obesity in adolescence on adult health status. Pediatrics. 2013;132(6):1098-104. doi: 10.1542/peds.2013-2185. [PubMed: 24249816]. 
21. Weiss R, Dziura J, Burgert TS, Tamborlane WV, Taksali SE, Yeckel CW, et al. Obesity and the metabolic syndrome in children and adolescents. NEnglJMed. 2004;350(23):2362-74. doi:10.1056/NEJMoa031049. [PubMed: 15175438].

22. Cook S, Weitzman M, Auinger P, Nguyen M, Dietz WH. Prevalence of a metabolic syndrome phenotype in adolescents: findings from the third National Health and Nutrition Examination Survey, 19881994. Arch Pediatr Adolesc Med. 2003;157(8):821-7. doi: 10.1001/archpedi.157.8.821. [PubMed: 12912790].

23. Lambert M, Paradis G, O’Loughlin J, Delvin EE, Hanley JA, Levy E. Insulin resistance syndrome in a representative sample of children and adolescents from Quebec, Canada. Int J Obes Relat Metab Disord. 2004;28(7):833-41. doi:10.1038/sj.ijo.0802694. [PubMed: 15170466].

24. Harel Z, Riggs S, Vaz R, Flanagan P, Harel D. Isolated low HDL cholesterol emerges as the most common lipid abnormality among obese adolescents. Clin Pediatr (Phila). 2010;49(1):29-34. doi: 10.1177/0009922809341076. [PubMed: 19628760].

25. Williams DP, Going SB, Lohman TG, Harsha DW, Srinivasan SR, Webber LS, et al. Body fatness and risk for elevated blood pressure, total cholesterol, and serum lipoprotein ratios in children and adolescents. Am J Public Health. 1992;82(3):358-63. [PubMed: 1536350].

26. Skinner AC, Perrin EM, Moss LA, Skelton JA. Cardiometabolic Risks and Severity of Obesity in Children and Young Adults. $N$ Engl J Med. 2015;373(14):1307-17. doi:10.1056/NEJMoa1502821. [PubMed: 26422721]

27. Healthy Study Group , Kaufman FR, Hirst K, Linder B, Baranowski T, Cooper DM, et al. Risk factors for type 2 diabetes in a sixth-grade multiracial cohort: the HEALTHY study. Diabetes Care. 2009;32(5):953-5 doi: 10.2337/dc08-1774. [PubMed: 19196888].
28. Marcus MD, Baranowski T, DeBar LL, Edelstein S, Kaufman FR, Schneider M, et al. Severe obesity and selected risk factors in a sixth grade multiracial cohort: the HEALTHY study. J Adolesc Health. 2010;47(6):604-7. doi: 10.1016/j.jadohealth.2010.04.017. [PubMed: 21094439].

29. Gomez-Ambrosi J, Catalan V, Ramirez B, Rodriguez A, Colina I, Silva C, et al. Plasma osteopontin levels and expression in adipose tissue are increased in obesity. J Clin Endocrinol Metab. 2007;92(9):3719-27. doi: 10.1210/jc.2007-0349. [PubMed:17595250].

30. Ahmad R, Al-Mass A, Al-Ghawas D, Shareif N, Zghoul N, Melhem M, et al. Interaction of osteopontin with IL-18 in obese individuals: implications for insulin resistance. PLoS One. 2013;8(5):e63944. doi: 10.1371/journal.pone.0063944. [PubMed: 23675517].

31. Speiser PW, Rudolf MC, Anhalt H, Camacho-Hubner C, Chiarelli F, Eliakim A, et al. Childhood obesity. J Clin Endocrinol Metab. 2005;90(3):1871-87. doi:10.1210/jc.2004-1389. [PubMed: 15598688].

32. Matteoni CA, Younossi ZM, Gramlich T, Boparai N, Liu YC, McCullough AJ. Nonalcoholic fatty liver disease: a spectrum of clinical and pathological severity. Gastroenterology. 1999;116(6):1413-9. [PubMed: 10348825].

33. Zhang $\mathrm{H}$, Yang $\mathrm{H}$, Lai C, Xu X, Huang K, Fu J. Quantitative relationship between liver fat content and metabolic syndrome in obese children and adolescents. Clin Endocrinol (Oxf). 2015;83(1):43-9. doi: 10.1111/cen.12758. [PubMed: 25711346].

34. Huang JS, Barlow SE, Quiros-Tejeira RE, Scheimann A, Skelton J, Suskind D, et al. Childhood obesity for pediatric gastroenterologists. J Pediatr Gastroenterol Nutr. 2013;56(1):99-109. doi: 10.1097/MPG.0b013e31826d3c62. [PubMed: 23282941]. 